\title{
HYDRATION MECHANISM AND STRENGTH OF OPC AND BLENDED OPC WITH FLY ASH IN THE PRESENCE OF METAKAOLIN
}

\author{
Anamika Singh ${ }^{1}$, Sukirti Gupta ${ }^{2}$, Janhavi Singh ${ }^{3}$, N.P Singh ${ }^{4}$ \\ ${ }^{1}$ Department of Chemistry, Udai Pratap Autonomous College Varanasi \\ ${ }^{2}$ Department of Chemistry, Udai Pratap Autonomous College Varanasi \\ ${ }^{3}$ Department of Chemistry, Udai Pratap Autonomous College Varanasi \\ ${ }^{4}$ Department of Chemistry, Udai Pratap Autonomous College Varanasi
}

\begin{abstract}
The infrastructural development is an important aspect for the overall development of country. In all construction works concrete is an important and costly issue, this governs the total cost of project. To reduce cement consumption for environmental and economical concern, use of supplementary materials is required. In this work fly ash and metakaolin were used to decrease the cement contents and increase the strength as well as durability of cement. The main objective of this research work is to know the cement hydration mechanism, its strength with different ratio of fly ash and metakaolin. All mixes were made with water-to-binder ratio of 0.40 . The results are evidences by chemical analysis, XRD, SEM, DSC, etc.
\end{abstract}

Keywords: OPC (Ordinary Portland cement); Mk (Metakaolin); FA (Fly ash), Blended cement; C-S-H(Calcium silicate hydrates); SEM, XRD; DSC.

\section{INTRODUCTION}

Now a day's whole word suffering from economical and environmental problems. For the economical growth we are ignoring the environmental problem but it is necessary to make a balance between them. There is a strong need to explore the possibility to reduce the use of naturally occurring pozzolonic materials and it can be done by the reuse of the by product (waste materials) which also reduce the $\mathrm{CO}_{2}$ produced during the processing of materials in order to human welfare concrete (1). For the production of 1 tone cement about 1 tone $\mathrm{CO}_{2}$ is produced. Per year about 250-260 million tones cement produced thus same amount of $\mathrm{CO}_{2}$ also produced (2-4). Now a day's some amount of cement is replaced by industrial, agricultural and chemical wastes which have pozzolonic or hydraulic properties (5-9). It reduces the use of primary materials and also $\mathrm{CO}_{2}$ emission which becomes environmental friendly.

Fly ash is a waste material of thermal power station. In our country disposal of fly ash is a huge problem. Recycle of fly ash geopolymer in OPC is very attractive as OPC is a common commodity in construction industry (10). In India, fly ash was used in Rihand dam construction replacing cement upto 15 percent is a best example of use of waste material in construction purpose to increase strength and quality of cement. There are two ways that the fly ash can be used: first way is to intergrind certain percentage of fly ash with cement clinker at factory to produce Portland pozzolana cement (PPC) and the second way is to use the fly ash as an admixture at time of making concrete at the site of work. The latter method gives freedom and flexibility to the researcher regarding the percentage addition of fly ash in order to improve the quality of cement.
The use of supplementary cementitious materials $\left(\mathrm{SCM}_{\mathrm{S}}\right)$ is fundamental part for the production of low cost construction materials for developing countries (11).From last two decades, there has been a growing interest in the use of metekaolin (MK) as supplementary cementitious material to impart an additional performance and good quality to concrete (12-16). Metekaolin is a thermally activated aluminosilicate material obtained by calcining or dehydroxylation of kaolin clay within the temperature range $750-800^{\circ} \mathrm{C}(17, \mathbf{1 8})$. In the case where insufficient or poor curing concrete structures like seashore, underground structures which undergo severe loss of compressive strength and permeability interconnected and durability. The use of metakaolin proves to be very useful to modify the properties of concrete.

Anhydrous cement does not bind fine and coarse aggregate. It acquires adhesive property only when mixed with water. The chemical reactions that take place between cement and water is referred as hydration of cement. So in this work hydration behavior were studied of blended OPC with fly ash in different percent i.e. 10, 15, 20 and then metakaolin 10 and $15 \%$ add. Different experimental work carried out like free lime test, non evaporable water content, setting time, Standard consistency, heat of hydration, compressive strength, soundness with different percentage of blended OPC with fly ash in presence of metakaolin. The advancement made in the various spheres of Science and Technology has helped us to recognize and understand the micro structure of cement compounds before and after hydration .XRD, SEM, DSC, studies helped to reveal the crystalline or amorphous structure of the unhydrated or hydrated Cement. Both fly ash and metakaolin increases the compressive strength of OPC (19). 


\section{EXPERIMENTAL PROCEDURE}

\subsection{Raw Material}

Ordinary Portland Cement: The cement used in this study was 43 grades from Jaypee Cement agency, Varanasi and properties are given in table-1

Fly ash: The fly ash used in this study was from Dadri power plant Its chemical composition and main physical properties are in table $2 \& 3$

Metakaolin: The metakaolin used in this study was from Kryton Build tech.Its chemical compositions are in table 4

Mix details: The fly ash proportion added to cement is studied by different literature. In practice optimal cement replacement ratios around 10-20 wt $\%$ are more frequently reported $\{\mathbf{1 9 - 2 1}\}$ but higher replacement ratios from 30 upto $55 \mathrm{wt} \%$ have also been found suitable for application $\{22-$ 23\}. So in this work 10, 15, $20 \mathrm{wt} \%$ Fly ash used and metakaolin 10 and $15 \mathrm{wt} \%$ according to Ordinary Portland cement was studied.

\subsection{Test Details}

Standard water consistency test: The water consistency of OPC with FA and MK were determined with the help of Vicat apparatus (IS: 4031 Part 4, 1988)

Determination of setting time: Initial and final setting of OPC with fly ash and MK were determined with the help of Vicat apparatus (IS: 4031 Part 5, 1988)

Preparation of hydrated samples: Hydrated samples were prepared with W/C or W/S ratio of 0.4 of different composition of OPC with FA and MK in polythene bags. The air inside the bags was removed in order to avoid carbonations. The hydration reaction were allowed to continue at room temperature and stopped at different time interval $(7,15,28,45)$ with isopropyl alcohol and diethyl ether. The hydrated samples were heated at $105^{\circ} \mathrm{C}$ for one hour. The dried samples were stored in polythene bags and kept in desiccator.

\section{Non-evaporable water content measurement: Approximately one gram of OPC with different composition of $\mathrm{FA}$ and $\mathrm{MK}$ for different time intervals weighed in ceramic crucibles and heated at $105^{\circ} \mathrm{C}$ for one hour in order to remove adsorbed water. When removed from the oven, the mass of crucibles and samples were determined again before placing them in a furnace at $1000^{\circ} \mathrm{C}$ for an hour. From mass losses at $1000^{\circ} \mathrm{C}$ is the non evaporable water content}

Free lime determination: Free lime of samples having different constituents and time (days) variable was determined by Franke method \{24-26\}. About $1 \mathrm{~g}$ of hydrated cement was refluxed with $40 \mathrm{ml}$ of isopropyl alcohol and acetoacetic ester mixture (20:3) for $1 \mathrm{hr}$. The solution was filtered and titrated against $0.1 \mathrm{~N} \mathrm{HCl}$ using bromophenol blue as an indicator. The percent of free lime was determined by using the following equation:

$$
\% \mathrm{CaO}=0.2804 * \mathrm{~V} / \mathrm{W}
$$

Where $\mathrm{V}=$ vol of $0.1 \mathrm{~N} \mathrm{HCl}$ used

$\mathrm{W}=$ wt of hydrated sample used

Soundness test of samples: Cylindrical moulds of LeChatellie equipment was filled with OPC with different composition of FA and MK were prepared having consistency 0.78 times of standard consistency of relevant compositions. After $24 \mathrm{hr}$ the cement cylinder were removed from water and measured the expansion then kept moulded samples in boiling water for $3 \mathrm{hr}$, cooled it and further measured the expansion. Difference in expansion is soundness of respective samples.

Heat of hydration measurement: Heat of hydration test is measured by product code of AIM-9934. The method of heat of hydration measurement is described in some literature also $\{27\}$

Compressive strength determination: Compressive strength of cement mortor of different composition were measured by the moulding of $185 \mathrm{~g}$ of cement with different compositions of FA, Mk and $555 \mathrm{~g}$ of sand and determined amount of water by trial and error process.

\section{METHOD OF ANALYSIS:}

SEM study: SEM images of OPC, OPC with FA and MK for 15 days \& 28 days were recorded from Birbal Sahani Institute of Palaeobotany, Lucknow by using model LEO 430

XRD study: XRD study of OPC, OPC with FA and MK for 15 days \& 28 days were recorded from Wockhardt Research Centre, Aurangabad, Maharashtra by using $\mathrm{Cu} \mathrm{K} \alpha$ radiations.

DSC study: DSC study of OPC, OPC with FA and MK for 28 days was recorded from Metallurgy Department, IIT BHU with NETZSCH DSC 404F3A analyser. Samples were heated in crucible upto $1300^{\circ} \mathrm{C}$ in an inert atmosphere $\left(\mathrm{N}_{2}\right)$.

\section{RESULT AND DISCUSSION}

In the concrete, cement chemically reacts with water and produces binding gel that binds other component together and creates stone type of material. The reaction process is called 'hydration' in which water is absorbed by the cement. In this process apart from the binding gel, some amount of lime $[\mathrm{Ca}(\mathrm{OH})]$ is also liberated. The coarse and fine aggregates act as filler in the mass

The main factors which determine the strength of concrete is amount of cement used and the ratio of water to cement in the concrete mix. However, there are some factors which limits the quantity of cement and ratio of water / cement to be used in the concrete. Hydration process of cement is 
exothermic and large amount of heat is liberated. Higher will be the cement content greater will be the heat liberation leading in distress to concrete.

Standard water consistency: The water required for standard consistency as a function of blended OPC with and without Mk are shown in [Table 5] and (Fig. 1)..Water is the principal constituent of the concrete mix. Once the concrete is hardened, the entrapped water in the mass is used by cement mineralogy for hydration and some water is evaporated, thus leaving pores in the matrix. Some part of these pores is filled with hydrated products of cement paste. It has been observed that higher the ratio of water / cement, higher is the porosity resulting in increased permeability. The value of standard water consistency increases as the proportion of FA and MK increases.

Setting time: The initial and final setting time of OPC and FA blended cement with and without Mk is shown in [Table 6] and (Fig. 2). As the amount of FA increases both initial and final setting time increases. In the presence of FA the retardation action takes place which strongly inhibits the growth of hydrates, this leads to the shifting of setting time to longer duration. The amount of Mk increases initial and final setting time decreases means hydration increases in presence of $\mathrm{Mk}$.

Non evaporable water content: Non evaporable water content gives us idea about the extent of chemically bounded water during hydration $\{\mathbf{2 8 - 2 9}$. It states that non evaporable value increases the extent of hydration also increases. So in this work it is found that moving from OPC to fly ash $\mathrm{Wn}$ value decreases but as the percentage of $\mathrm{Mk}$ increses the value of $\mathrm{Wn}$ increases. So $\mathrm{Wn}$ is more at all hydration periods in the presence of $\mathrm{Mk}$ indicating that there is pozzolanic reaction forming more hydration product responsible for enhanced compressive strength.

Free lime: Normally free lime $(\mathrm{CaO})$ is present in clinker whereas in cement major portion is present as calcium hydroxide. As free lime value decreases hydration rate decreases. It is observed that in this paper, the value of free lime of OPC in presence of FA and Mk is less than that of OPC. As the percentage of $\mathrm{Mk}$ increases, the free lime content decreases because it reacts with free lime to form addition C-S-H material, thereby making the cement stonger and durable.

Soundness: Soundness test indicate the rate of volume change and results were presents in [Table 9] and (Fig. 5). In accordance to IS standard the expansion for OPC ranges in between $0.75 \mathrm{~mm}$ to $1.00 \mathrm{~mm}$. The cement is said to be sound when the percentage of free lime and magnesia is within specified limits. These materials expand in structure. From Fig-5 it is clear that as fly ash added to OPC soundness decreases. These decreasing behaviors continue with variation of in percentage of $\mathrm{Mk}$ in blended OPC which suggests that free lime and magnesia is within limits.

Heat of Hydration: Change of heat of hydration with different compositions is in [Table 10] and (Fig. 6). Heat of hydration gives idea about the rate of hydration. As from graph OPC have maximum heat of hydration. By the addition of fly ash heat of hydration lowers means hydration rate decreases but as $\mathrm{Mk}$ increases heat of hydration increases that increased heat evolved corresponds to increase in the strength. And we also observe that 28 days have more heat of hydration value than 15 days i.e. 15 days to 28 days hydration rate increases.

Compressive strength: Compressive strength gives idea about the strength of cement. From table-11 and Fig-6 it is clear that compressive strength increases as percent of fly ash increases in OPC. From fig it is also observed that compressive strength further increases due to pozzolonic reaction of $\mathrm{Mk}$ with $\mathrm{CH}$. As hydration time increases compressive strength increases due to formation of compact mass.

SEM analysis: The SEM photographs of hydrated OPC and Fly ash blend in the presence of $\mathrm{Mk}$ are given in Fig10.Hydrated product like Calcium hydroxide $[\mathrm{CH}]$, tobermorite $[\mathrm{C}-\mathrm{S}-\mathrm{H}]$ appeared, due to chemical reactions are found in SEM pictures. In presence of Mk hydrated grains are combined with $\mathrm{CH}$ and form continuous mass structure which is called C-S-H gel. The mass structure in all composition increases from 15 days to 28 days.The occurrence of C-S-H in large quantity in presence of $\mathrm{Mk}$ is responsible for compactness of cement particle and producing a rigid system. Thus blended OPC in presence of $\mathrm{Mk}$ give more rigidity and compactness.

XRD analysis: I found that XRD spectra have suggested the presence of hydration product like portlandite, ettringite, tobermorite and also unhydrated minerals $\{30-31\}$. XRD (Fig-8) showsthat portlandite peak decreases in height from OPC to OPC with $15 \%$ FA and in presence of Mk height increases which evidence the setting time behavior of both FA and Mk. The ettringite, $\mathrm{C}_{3} \mathrm{~S}, \mathrm{C}_{2} \mathrm{~S}$ and $\mathrm{CH}$ peak as such .From graph it is very much clear that hydration reaction is same in all compositions and only extent of hydration changes.

DSC analysis: DSC thermograph of 28 days hydrated sample showed changes at four temperature variables (fig9). First between $150-200^{\circ} \mathrm{C}$ which is due to elimination of adsorbed water molecule. From OPC to blended OPC peak broaden at that temperature shows that the standard consistency increases in blended OPC. Second changes takes between $400-500^{\circ} \mathrm{C}$ corresponds to decomposition of $\mathrm{Ca}(\mathrm{OH})_{2}$ formed during hydration. In graph at that temperature from OPC to blended OPC in presence of $\mathrm{Mk}$ peak area decreases which is due to pozzolonic activity and $\mathrm{Ca}(\mathrm{OH})_{2}$ consumption. Third changes between $600-800^{\circ} \mathrm{C}$ is due to the decomposition of $\mathrm{CaCO}_{3}$. More the $\mathrm{CaCO}_{3}$ decomposes more free lime will be produced. In graph OPC have broad peak area than blended OPC with and without $\mathrm{Mk}$. This indicates the lower value of free lime from OPC to blended OPC with and without $\mathrm{Mk}$. The changes from $1250-1300^{\circ} \mathrm{C}$ takes place which is due to phase transformation. 
Table -1 chemical analysis of 43 grade OPC

\begin{tabular}{|l|l|}
\hline Chemical analysis & $\begin{array}{l}\text { Result } \\
\text { obtained }\end{array}$ \\
\hline Lime saturation factor ( LSF ) & 0.85 \\
\hline Alumina/ Iron Oxide ratio ( $)$ & 1.33 \\
\hline Insoluble residue ( \% by mass) & 0.65 \\
\hline Magnesia (\% by mass) & 2.56 \\
\hline Sulphuric anhydride $\%$ by mass) & 1.85 \\
\hline Total LOI (\% by mass) & 0.85 \\
\hline Chloride (\% by mass) & 0.013 \\
\hline
\end{tabular}

Table-2 Chemical composition of fly ash

\begin{tabular}{|c|c|c|c|c|c|c|c|c|c|}
\hline $\begin{array}{l}\text { Miner } \\
\text { als }\end{array}$ & $\begin{array}{l}\mathrm{Si} \\
\mathrm{O} \\
2\end{array}$ & $\begin{array}{l}\mathrm{Al}_{2} \\
\mathrm{O}_{3}\end{array}$ & $\begin{array}{l}\mathrm{Fe}_{2} \\
\mathrm{O}_{3}\end{array}$ & $\begin{array}{l}\mathrm{C} \\
\mathrm{a} \\
\mathrm{O}\end{array}$ & $\begin{array}{l}\mathrm{M} \\
\mathrm{g} \\
\mathrm{O}\end{array}$ & $\begin{array}{l}\mathrm{S} \\
\mathrm{O} \\
3\end{array}$ & $\begin{array}{l}\mathrm{Na}_{2} \\
\mathrm{O}\end{array}$ & $\begin{array}{l}\mathrm{K}_{2} \\
\mathrm{O}\end{array}$ & $\begin{array}{l}\mathrm{L} \\
\mathrm{O} \\
\mathrm{I}\end{array}$ \\
\hline $\begin{array}{l}\% \text { in } \\
\text { FLY } \\
\text { ash }\end{array}$ & $\begin{array}{l}44 \\
.0\end{array}$ & $\begin{array}{l}23 . \\
4\end{array}$ & $\begin{array}{l}17 . \\
7\end{array}$ & $\begin{array}{l}3 . \\
7\end{array}$ & $\begin{array}{l}0 . \\
8\end{array}$ & $\begin{array}{l}0 . \\
9\end{array}$ & 0.8 & 0.8 & $\begin{array}{l}5 . \\
7\end{array}$ \\
\hline
\end{tabular}

Table-3 Physical property of fly ash

\begin{tabular}{|l|l|}
\hline Physical property & Result \\
\hline Specific gravity & 2.22 \\
\hline Blain fineness $\left(\mathrm{cm}^{2} / \mathrm{g}\right)$ & 2830 \\
\hline Median particle size $(\mu \mathrm{m})$ & 30.6 \\
\hline
\end{tabular}

Table-4 Chemical composition of metakaolin

\begin{tabular}{|l|l|}
\hline chemicals & Percentage ( \% ) \\
\hline $\mathrm{SiO}_{2}$ & 62.62 \\
\hline $\mathrm{Al}_{2} \mathrm{O}_{3}$ & 28.63 \\
\hline $\mathrm{Fe}_{2} \mathrm{O}_{3}$ & 1.07 \\
\hline $\mathrm{MgO}$ & 0.15 \\
\hline $\mathrm{CaO}$ & 0.06 \\
\hline $\mathrm{Na} 2$ & 1.57 \\
\hline $\mathrm{K}_{2} \mathrm{O}$ & 3.46 \\
\hline $\mathrm{TiO}_{2}$ & 0.36 \\
\hline
\end{tabular}

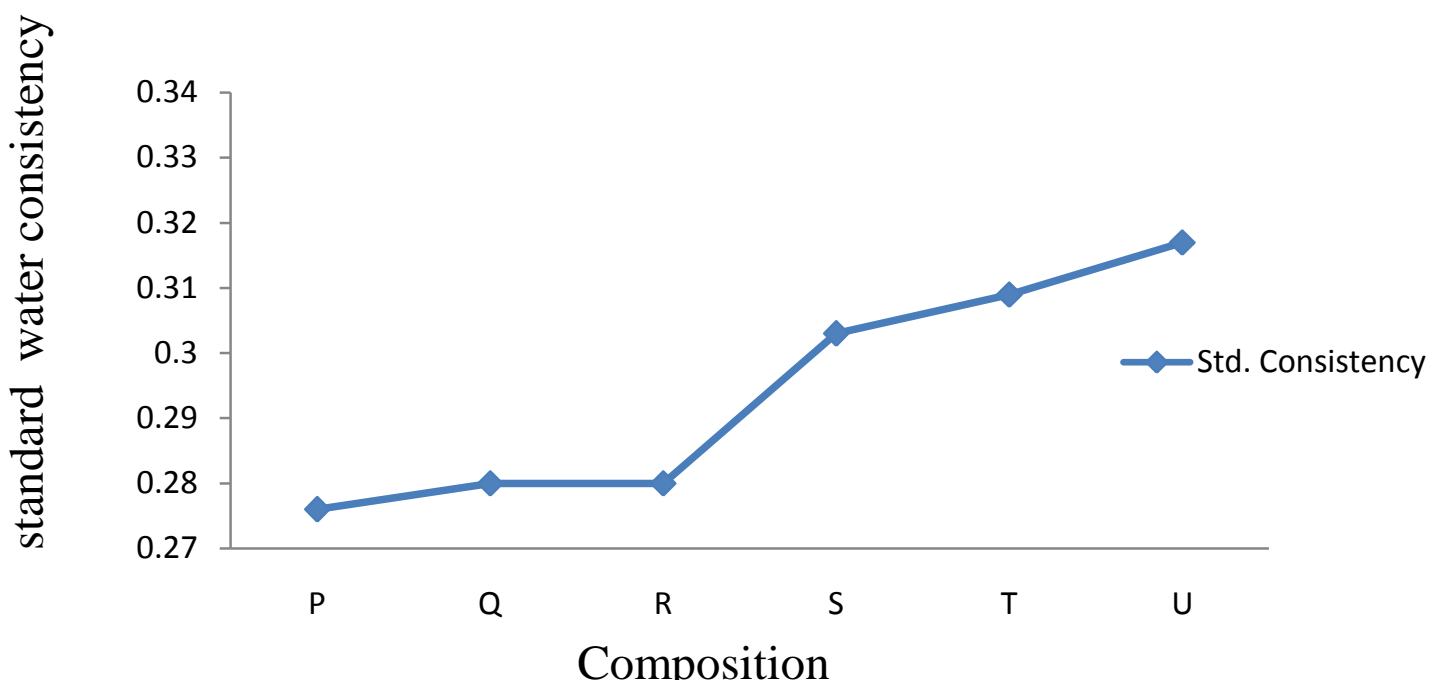

Fig. 1 Standard Water Consistency $\mathrm{P}=\mathrm{OPC}, \mathrm{Q}=\mathrm{OPC}+15 \% \mathrm{FA}, \mathrm{R}=\mathrm{OPC}+10 \% \mathrm{Mk}, \mathrm{S}=\mathrm{OPC}+15 \% \mathrm{Mk}$, $\mathrm{T}=\mathrm{OPC}+15 \% \mathrm{FA}+15 \% \mathrm{Mk}, \mathrm{U}=\mathrm{OPC}+15 \% \mathrm{FA}+15 \% \mathrm{Mk}$

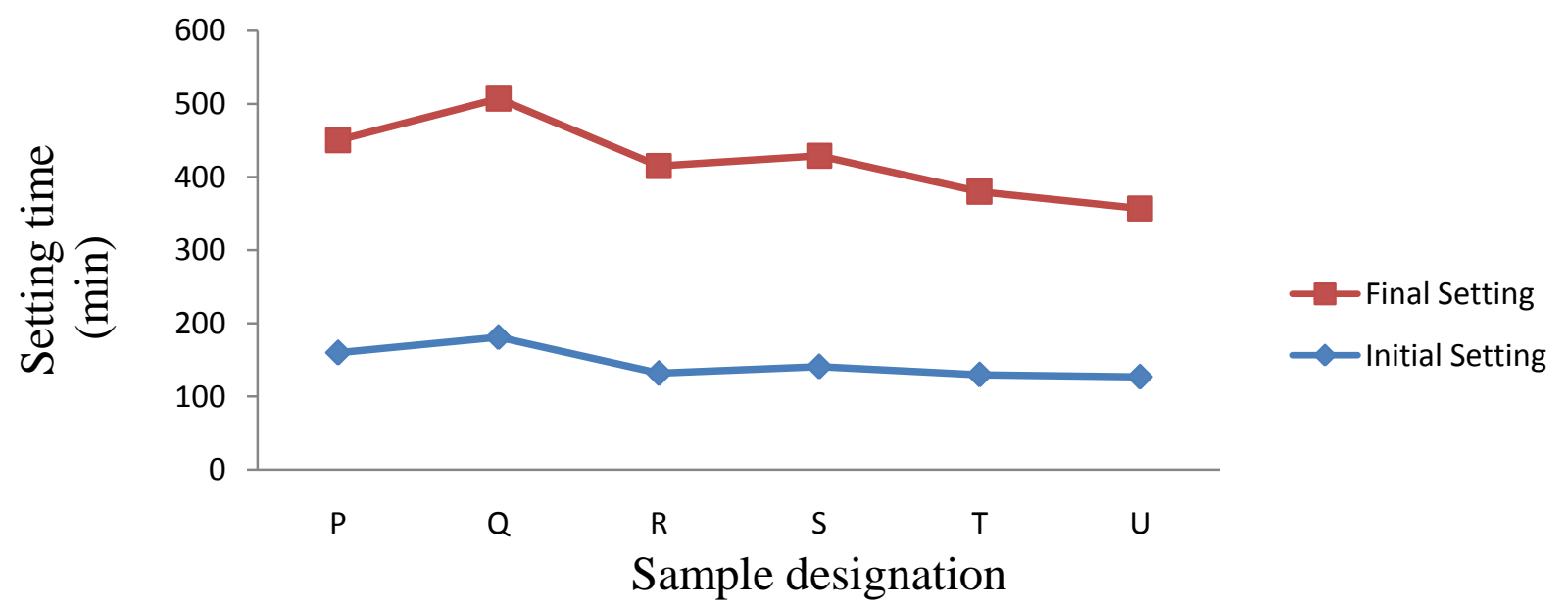

Fig. 2 Initial and Final Setting time (minutes) $(\mathrm{P}=\mathrm{OPC}, \mathrm{Q}=\mathrm{OPC}+15 \% \mathrm{FA}, \mathrm{R}=\mathrm{OPC}+10 \% \mathrm{Mk}, \mathrm{S}=\mathrm{OPC}+15 \% \mathrm{Mk}$, $\mathrm{T}=\mathrm{OPC}+15 \% \mathrm{FA}+15 \% \mathrm{Mk}$, $\mathrm{U}=\mathrm{OPC}+15 \% \mathrm{FA}+15 \% \mathrm{Mk})$ 


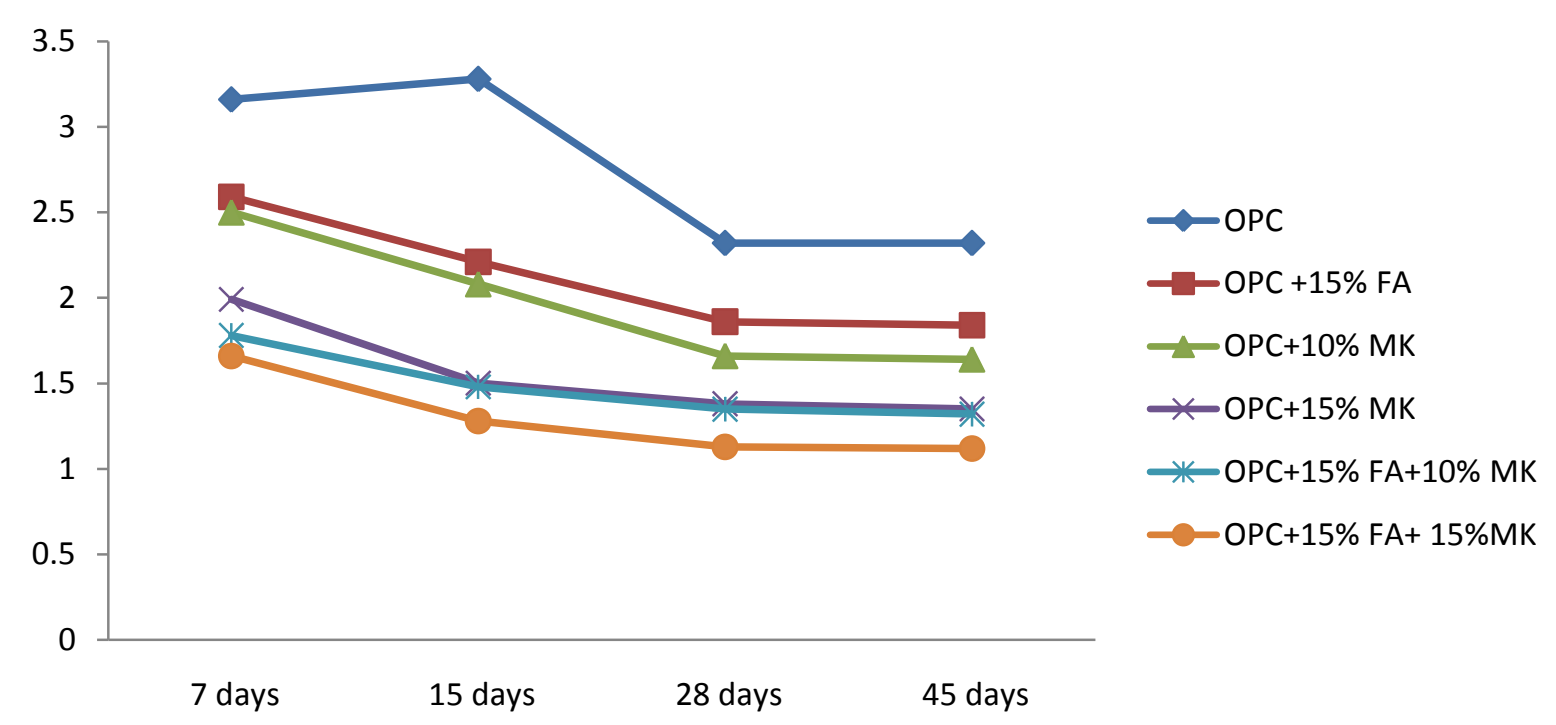

Fig. 3 free lime change with hydration time

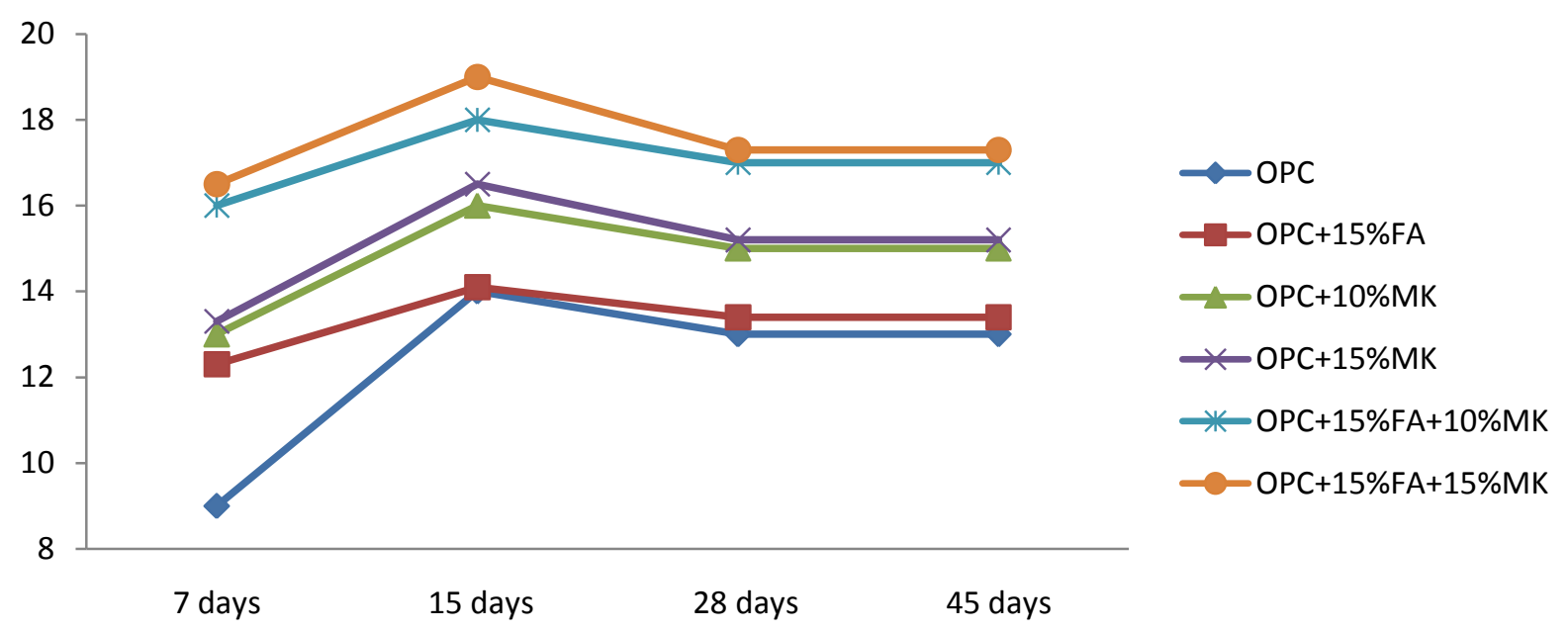

Fig. 4 Change of Non-evaporable water content with hydration time

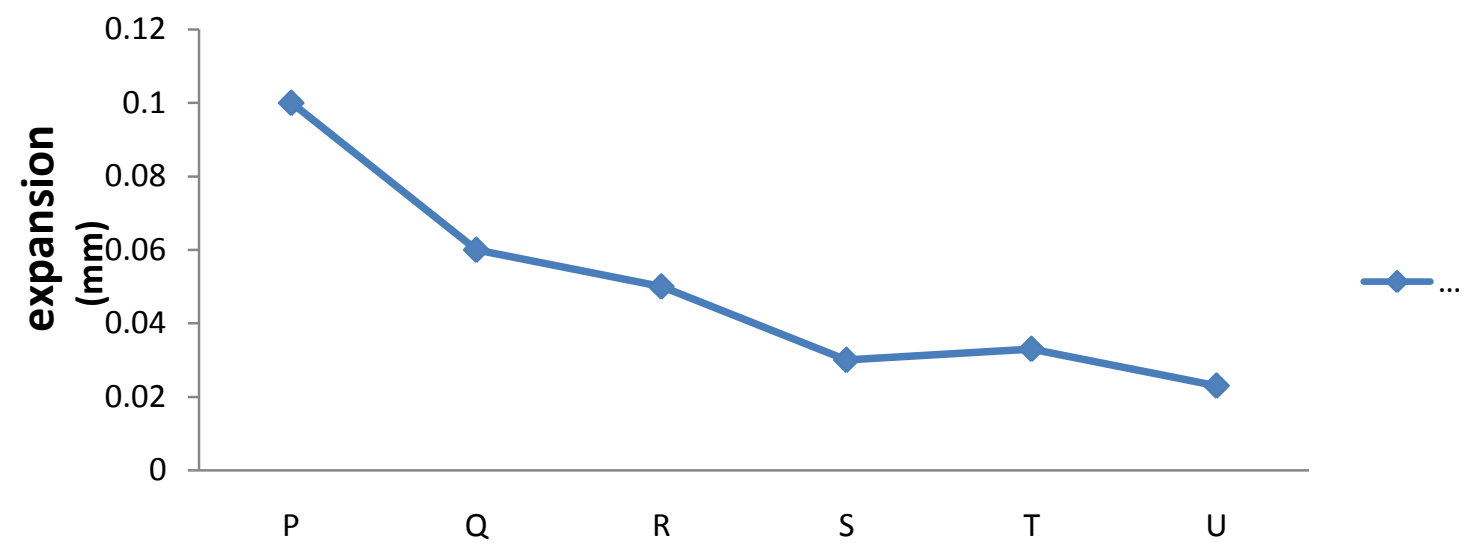

\section{Composition}

Fig. 5 Soundness test of sample $\mathrm{P}=\mathrm{OPC}, \mathrm{Q}=\mathrm{OPC}+15 \% \mathrm{FA}, \mathrm{R}=\mathrm{OPC}+10 \% \mathrm{Mk}, \mathrm{S}=\mathrm{OPC}+15 \% \mathrm{Mk}, \mathrm{T}=\mathrm{OPC}+15 \% \mathrm{FA}+15 \% \mathrm{Mk}$, $\mathrm{U}=\mathrm{OPC}+15 \% \mathrm{FA}+15 \% \mathrm{Mk}$ 


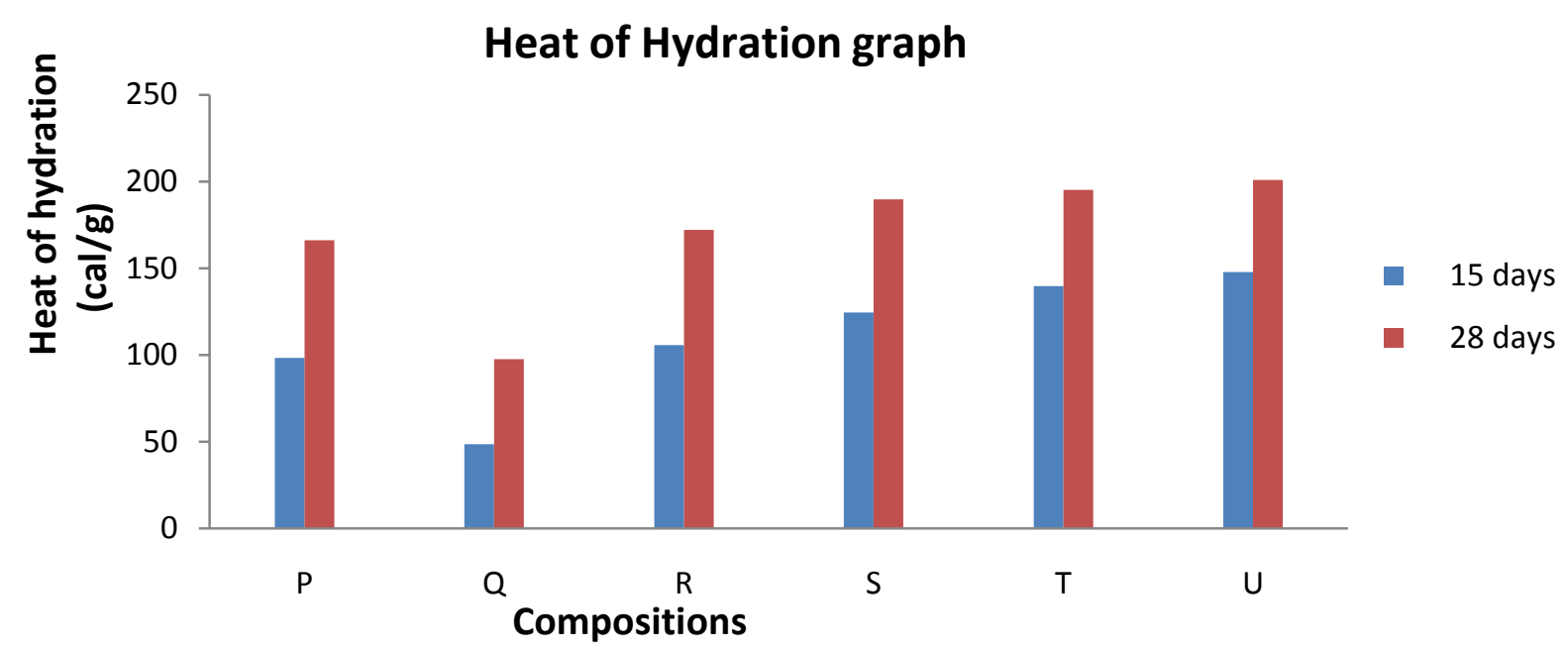

Fig. 6 Change of heat of hydration with hydration time $\mathrm{P}=\mathrm{OPC}, \mathrm{Q}=\mathrm{OPC}+15 \% \mathrm{FA}, \mathrm{R}=\mathrm{OPC}+10 \% \mathrm{Mk}, \mathrm{S}=\mathrm{OPC}+15 \% \mathrm{Mk}$, $\mathrm{T}=\mathrm{OPC}+15 \% \mathrm{FA}+15 \% \mathrm{Mk}, \mathrm{U}=\mathrm{OPC}+15 \% \mathrm{FA}+15 \% \mathrm{Mk}$

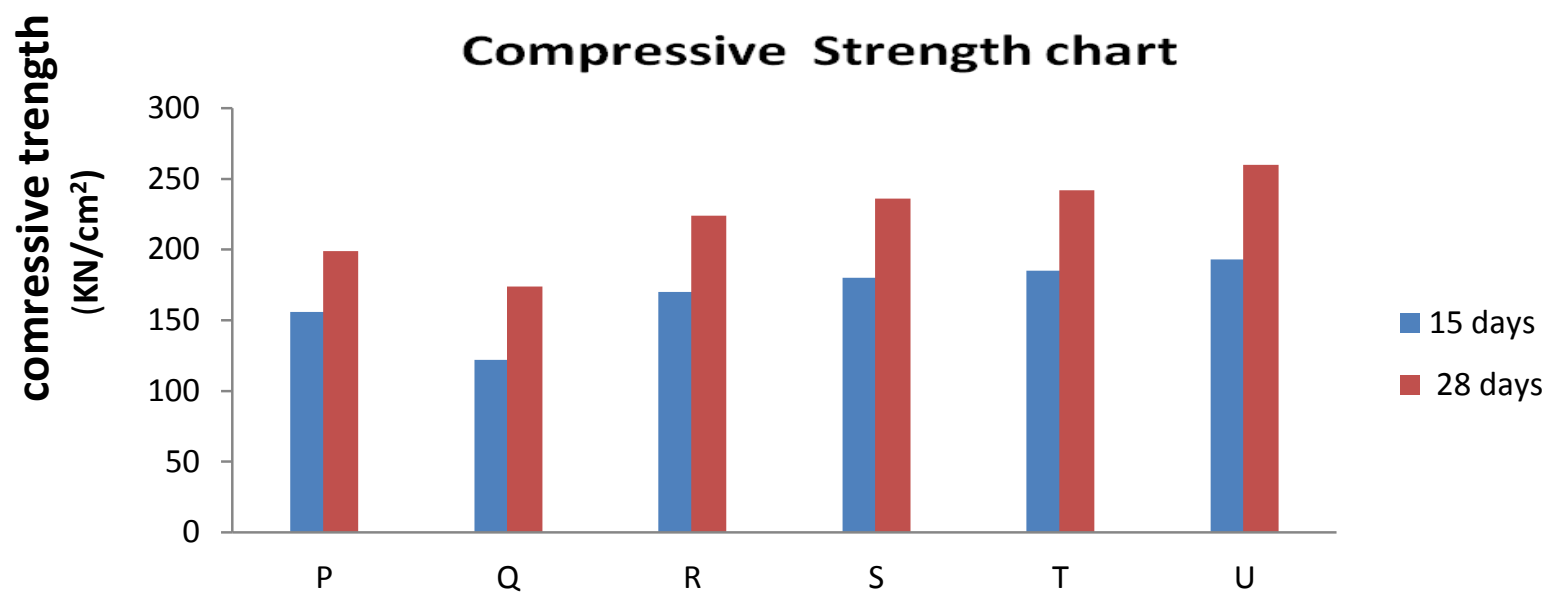

\section{Compositions}

Fig. 7 Change of compressive strength with hydration time $\mathrm{P}=\mathrm{OPC}, \mathrm{Q}=\mathrm{OPC}+15 \% \mathrm{FA}, \mathrm{R}=\mathrm{OPC}+10 \% \mathrm{Mk}, \mathrm{S}=\mathrm{OPC}+15 \% \mathrm{Mk}$, $\mathrm{T}=\mathrm{OPC}+15 \% \mathrm{FA}+15 \% \mathrm{Mk}, \mathrm{U}=\mathrm{OPC}+15 \% \mathrm{FA}+15 \% \mathrm{Mk}$

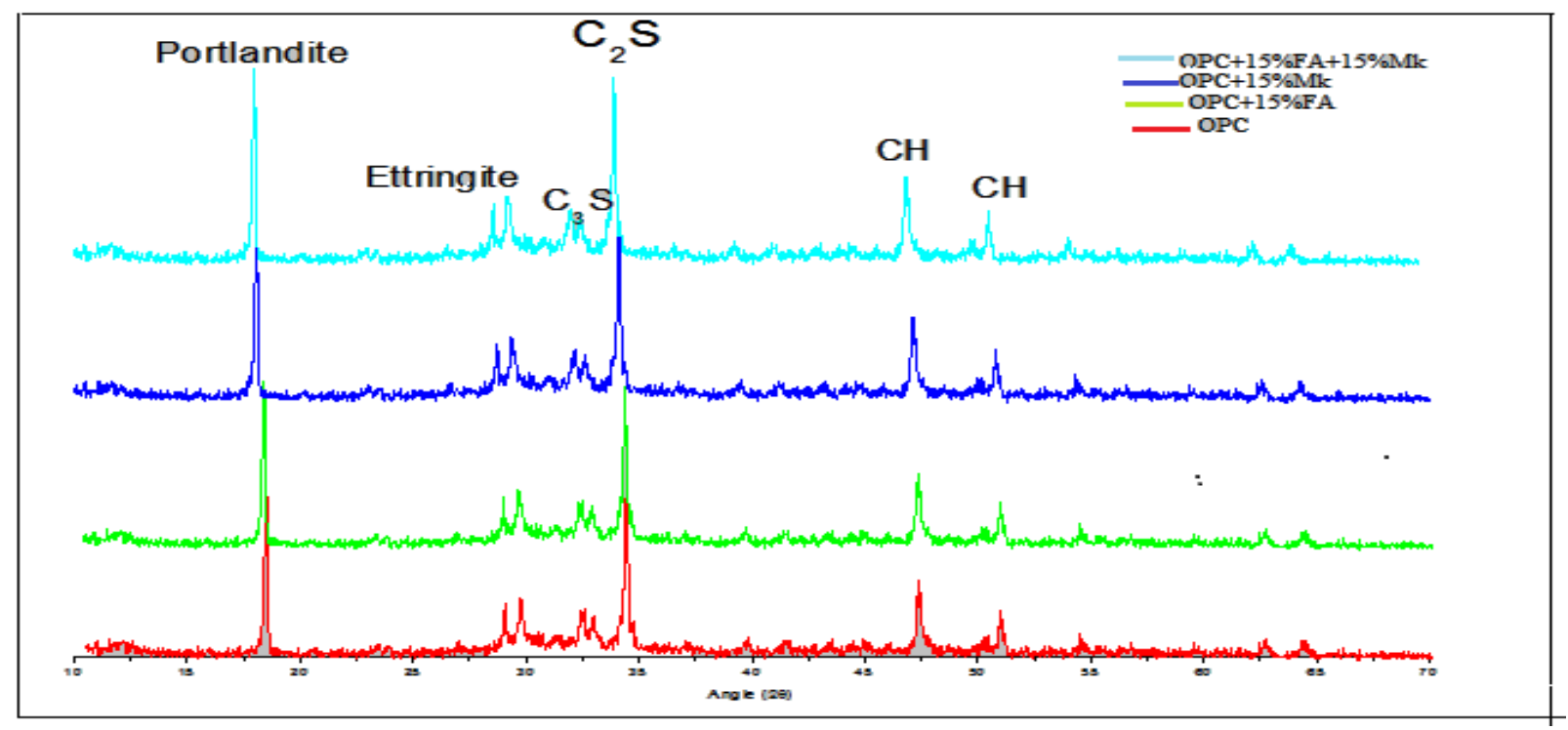

Fig. 8 XRD of 28 days hydrated sample 


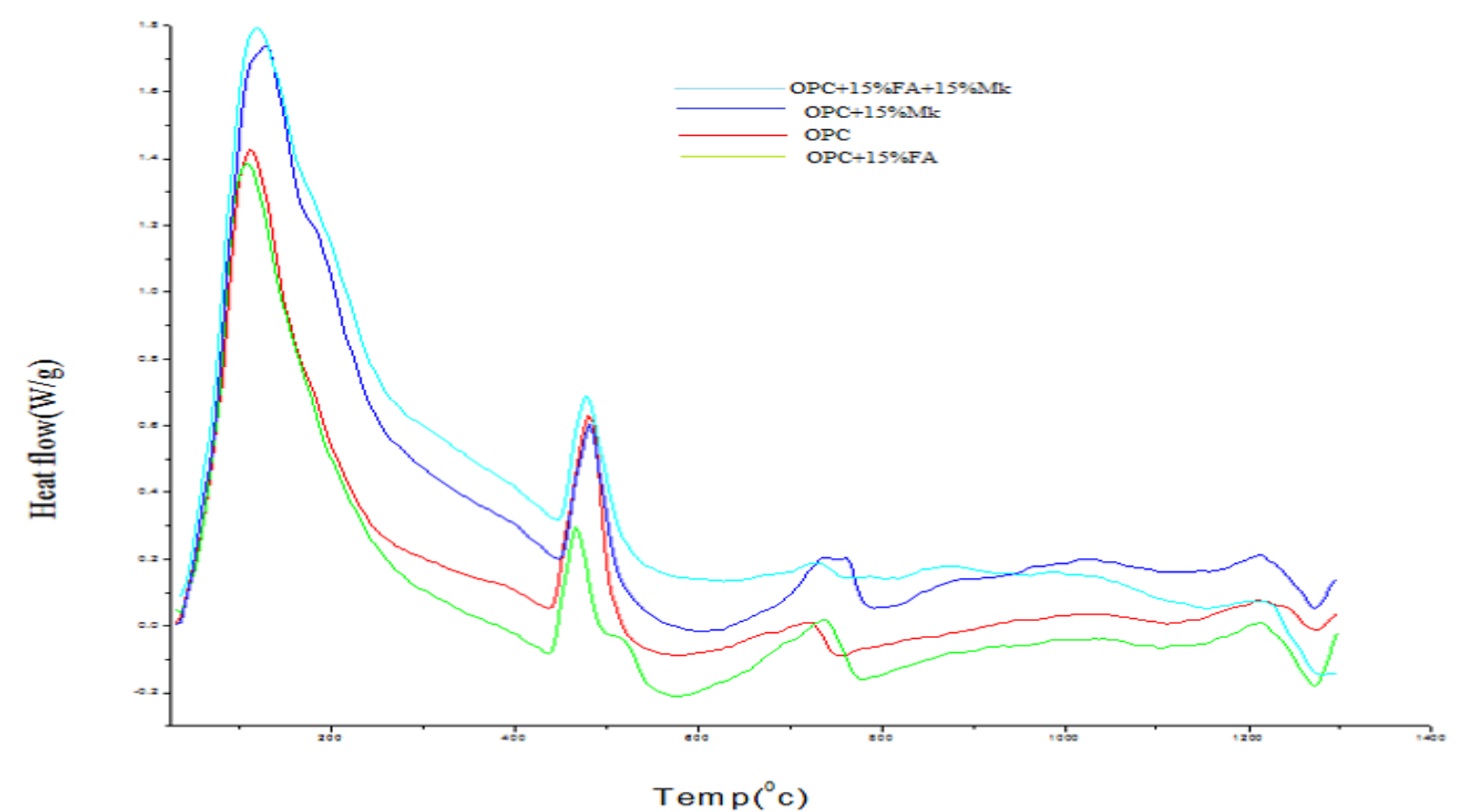

Fig. 9 DSC of 28 days hydrated sample

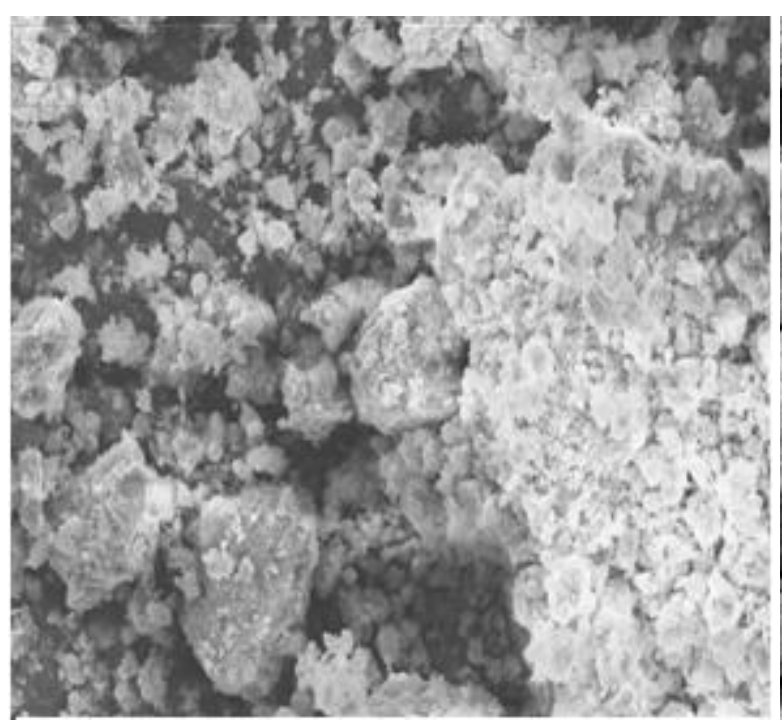

OPC 15 Days

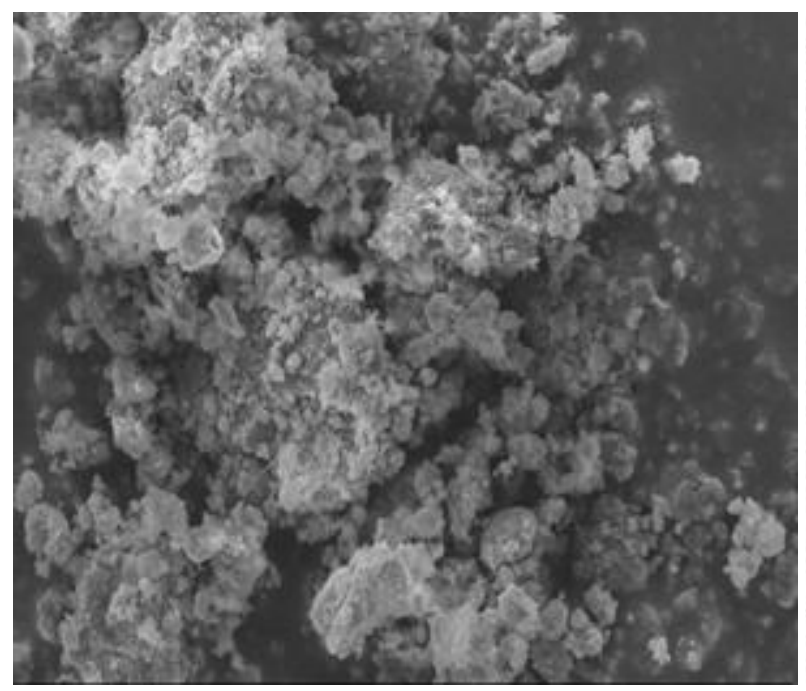

OPC+15\%FA 15 Days
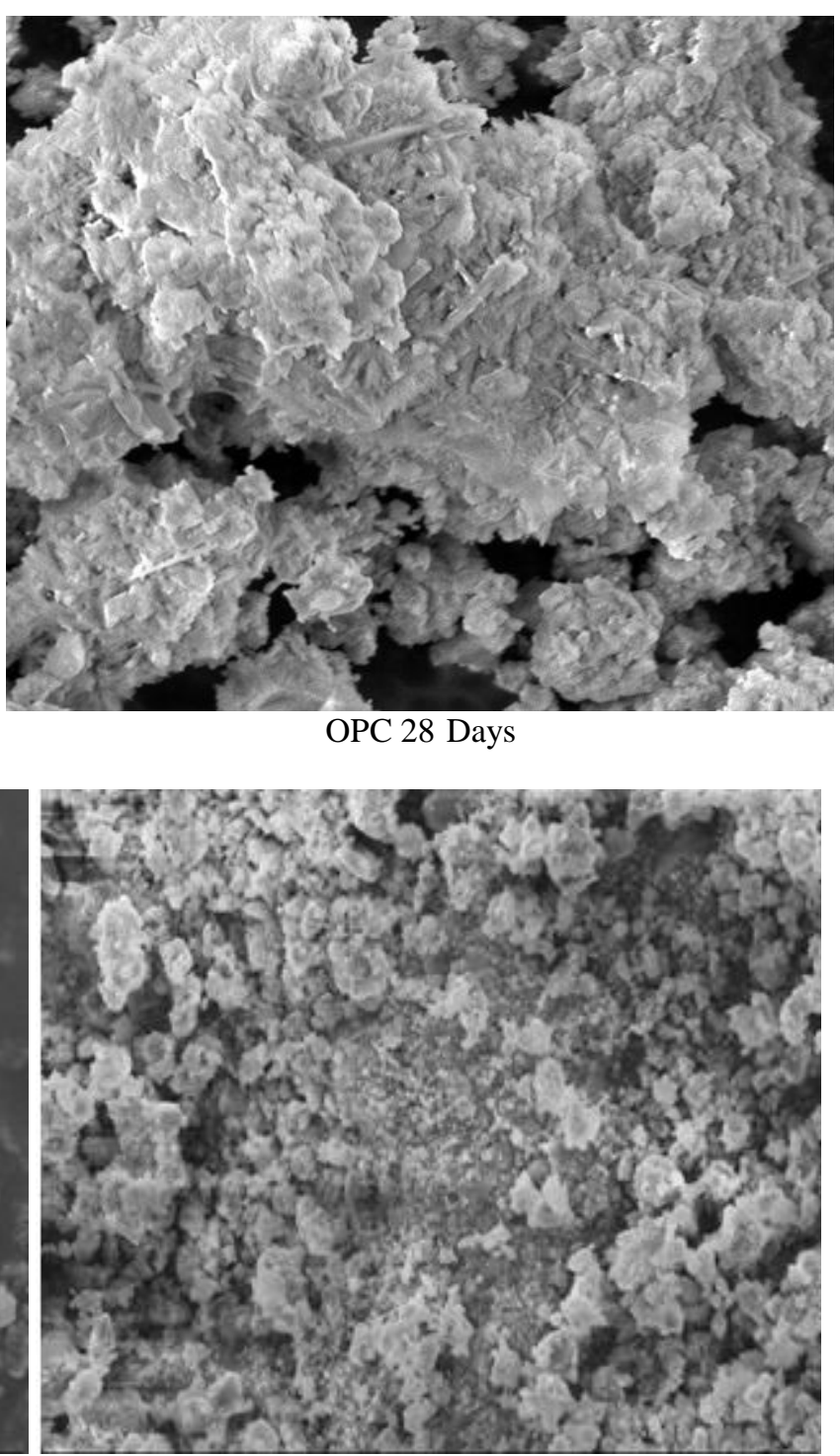

OPC $+15 \%$ FA 28 Days 


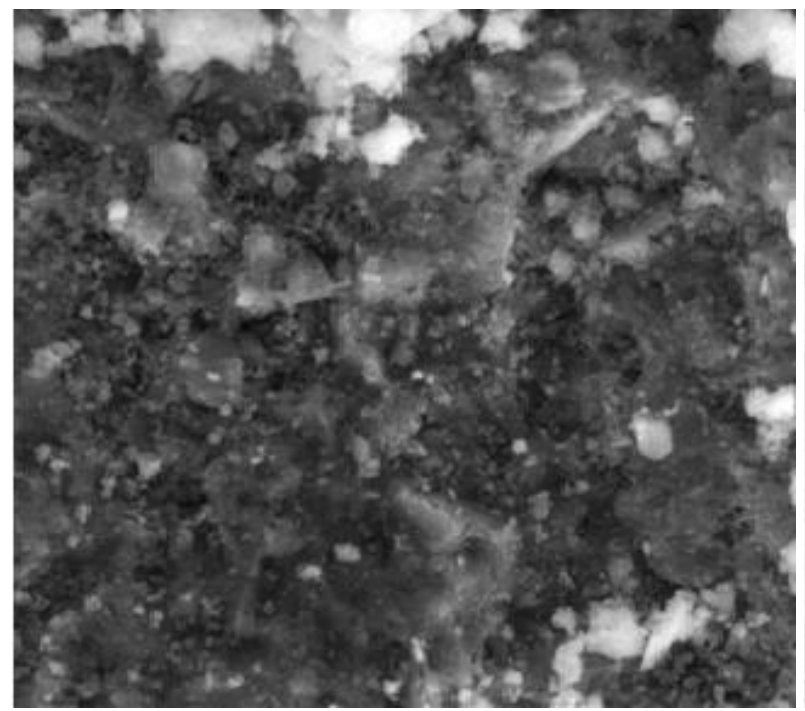

OPC+15\%MK 15 Days

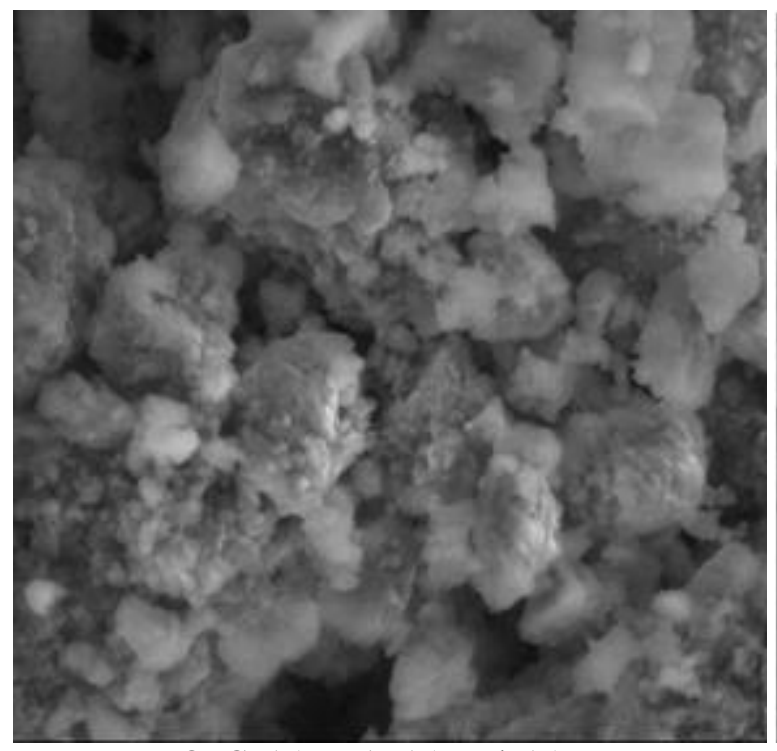

OPC+15\% FA+15\%Mk 15 Days

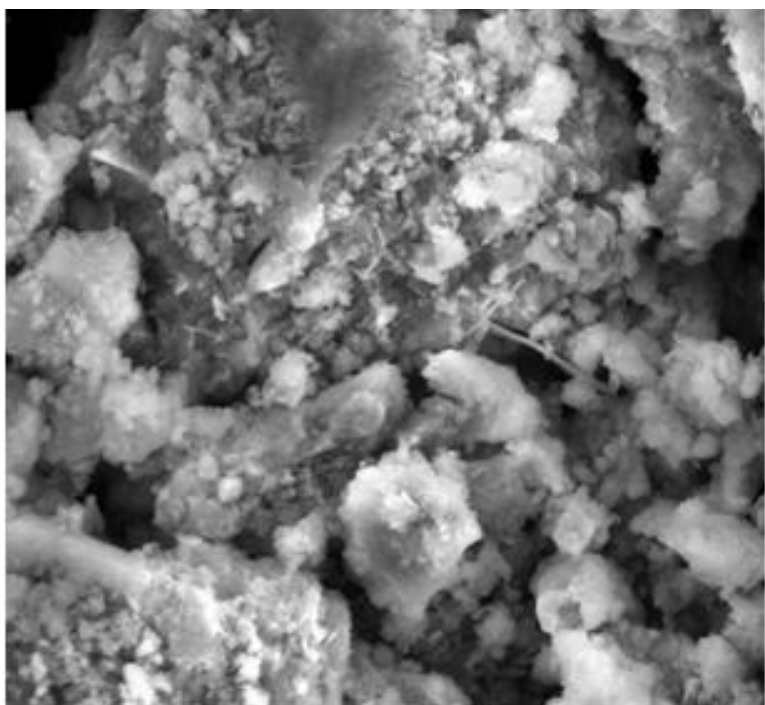

OPC $+15 \%$ MK 28 Days

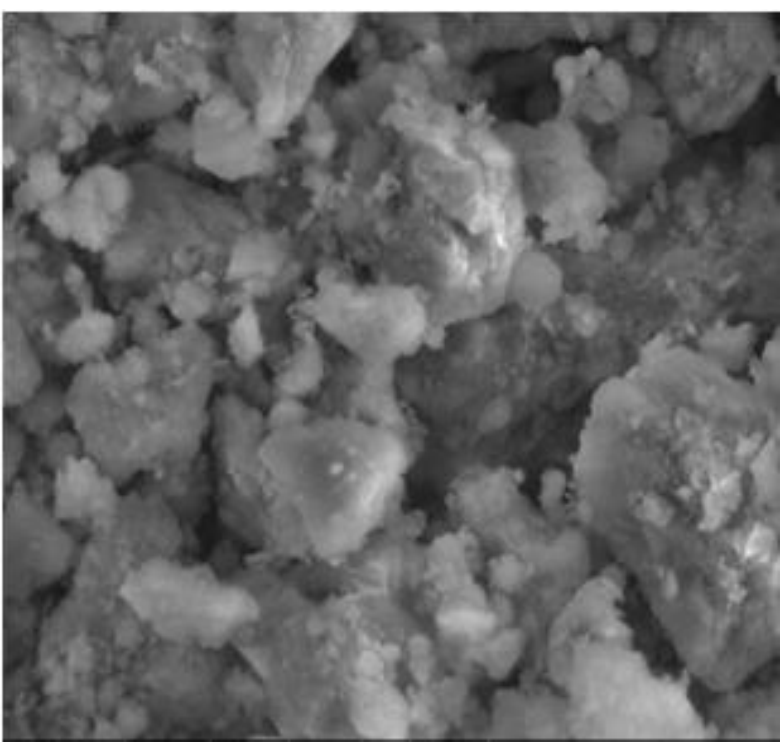

OPC+15\% FA+15\%Mk 28 Days

Fig. 10 SEM of 15 days and 28 days hydrated Sample

\section{CONCLUSION}

- The water demand for standard consistency increases with increase of FA and Mk content.

- The addition of FA to OPC prolonged the initial and final setting time but in the presence of Mk setting time decreases.

- Non evaporable water content is more in blended cement at all hydration periods which indicates that pozzolonic reaction enhances and more hydration product formed.

- Free lime decreases with increase of Mk content because $\mathrm{Mk}$ reacts with free lime during hydration to form addition $\mathrm{C}-\mathrm{S}-\mathrm{H}$ material, thereby making the cement stronger and durable.

- Compressive strength value at 28 days hydration period is more due to larger extent of less porous hydration product.
- $\quad$ XRD and DSC analysis indicates that addition of Mk in FA blended cement does not alter the hydration product but only modify the rate of hydration.

- SEM photos indicating that in presence of $\mathrm{Mk}$ hydration products are more dense and less porous which increase the durability of cement.

- Finally we concluded that FA does not give early strength but Mk provides strength at early age of hydration in FA blended cement.

\section{ACKNOWLEDGEMENTS}

Authors are very thankful to the department of chemistry U.P.Autonomous college, Varanasi for providing laboratory facilities. Authors are very thankful to the department of Physics, metallurgy and civil engineering IIT BHU, Varanasi for providing help in XRD, DSC, SEM and compressive strength facilities. 


\section{REFERENCES}

[1] Rajendra Rajdev, Shalini Yadav, Rakesh Sakle; Comparison between Portland Pozzolana Cement \& Processed Fly Ash blended Ordinary Portland Cement Civil and Enviromental Research, 3 (2013)

[2] Mieke De Schepper, Ruben Snellings, Klaartji De Buysser, Isabel Van Driessche, Nele De Belie; The hydration of cement regenerated from Completely Recyclable Concrete Construction and Building materials, 60 , 2014 , 33-41

[3] J.S. Damtoft, J. Lukasik, D. Herfort, D Sorrentino, E M Gartner, Sustainable development and climate change initiatives, Cement and concrete research, 38, 2008, 115-127

[4] E Garther, Industrially interesting approaches to "low-CO2" cements, Cement and

[5] concrete research 34, (9) 2004, 1489-98

[6] E. Grayaert, Philip Van den Heede, Nele De Belie; Carbonation of slag concrete: Effect of the cement replacement level and curing on the carbonation coefficient - Effect of carbonation on the pore structure, Cement and concrete composites, 35, (1) 2013, 39-48

[7] Florian Deschner, Frank Winnerfeld, Barbara Lothenbach et al; Hydration of Portland

[8] cement with high replacement by siliceous fly ash, Cement and concrete research, 42, 2012, 1389-1400

[9] I A Chen, M.C.G. Juenger, Incorporation of Waste Materials into Portland Cement Clinker Synthesized from Reagent-Grade Chemicals, Int. J. Appl Ceram Technology, 6 , 2009, 270-278

[10] A Monshi, M K Asgarani, Producing Portland cement from iron and steel slags and limestone, Cement and concrete research, 29, 1999, 1373-1377

[11] M Schneider, M Romer, M Tschlidin, H Bolio, Sustainable cement production-present and future, Cement and concrete research, 41, 2011, 642-50

[12] Saenqsuree Pangdaeng, Tanakorn Phoo-ngernkham, Vanchai Sata, Prinya Chindaprasirt; Influence of curing conditions on properties of high calcium fly ash geopolymer containing Portland cement as additive, Material and Design 53, 2014, 269-274

[13] Nova John, Strength Properties of Metakaolin Admixed Concrete International Journal of scientific and research publication, 3, (6), 2013, ISSN- 22503153

[14] B B Sabir, S Wild, J Bai, Metakaolin and calcined clay as pozzolans for concrete :a review, Cement and concrete Composites, 23, 2001, 441-54

[15] G Kakali, T Perraki, S Tsivilis, E Badogiannis, Thermal treatment of kaolin: the effect of mineralogy on the pozzolanic activity, Appl Clay Science, 20, 2001, 73-80

[16] S Wild, J M Khatip, A Jones, : Relative strength, pozzolanic activity and cement hydration in superplasticized metakaolin concrete, Cement and concrete research, 26, 1996, 1537-44

[17] E Guneyisi, K Mermerdas, Comparative study on strength, sorptivity, and chloride ingress characteristics of air-cured and water-cured concretes modified with metakaolin Mater Struct, 40, 2007, 1161-71
[18] E Guneyisi, M Gesoglu, K Mermerdas, Improving strength, drying shrinkage, and pore structure of concrete using metakaolin. Mater Struct, 41, 2008, 937-49

[19] D S Klimesch, A Ray, Use of the second-derivative differential thermal curve in the evaluation of cement-quartz pastes with metakaolin addition autoclaved at $180^{\circ} \mathrm{C}$.

[20] Thermochem Acta, 307 ( 2 ), 1997, 167-76

[21] D S Klimesch, A Ray, Autoclaved cement-quartz pastes with metakaolin addition

[22] Adv. Cem Based Mater, 7 (3), 1998, 109-18

[23] G Murali, P Sruthee, "Experimental study of concrete with metakaolin as partial replacement of cement, International Journal of Emerging trends in Engineering and Development 4 ,(2), 2012, ISSN2249-6149

[24] L. Huzhien, Preceeding of the $9^{\text {th }}$ international congress on the chemistry of cement, New Delhi, India, 1992, 128-134

[25] F.Conpalant, K.Yilmaz, M.M.koso, M.Sumer, M.A.Yurdusew, Use of zeolite, coal bottom ash and fly ash as replacement materials in cement production, Cement and concrete research, 34 (2004) 731-735

[26] N.Q.Feng, G.F.Peng, Applications of natural zeolite to construction and building materials in China, Constr. Build. Mater, 19 (2005) 579-584

[27] R.Sersale, G.Frigione, Portland-zeolite-cement for minimizing alkali-aggregate expansion, Cement and concrete research, 17 (1987) 404-410

[28] B.Uzal, L.Turvanli, Studies on blended cements containing a high volume of natural pozzolans, Cement and concrete research, 33 (2003) 1777-1781

[29] E.E.Pressler, S.Brunauer, Investigation of the Franke method of determining free calcium hydroxide and free calcium oxide, Anorg. Allg. Chem., 28 (1956) 896-902

[30] M.P. Javellena, I. Jawed, Extraction of free lime in Portland cement and clinker by ethylene glycol, Cem. Concr. Res. 12 (1982) 399-403.

[31] S. Newman Edwin and S. Wells Lansing, Heats of Hydration and Pozzolan Content of PortlandPozzolan Cements, Journal of Research of the national Bureau of standards 49 (1952) RP-2342

[32] Qiang zeng, Kefei Li , Teddy Fen- chong, Determination of cement hydration and pozzolanic reaction extents for fly-ash cement pastes, Constr. Build. Mater, 27 (2012) 560-569

[33] Text book on Cement Chemistry by H.W. Taylor

[34] Jumate et al, X-Ray Diffraction Study Of Hydration Processes In The Portland Cement Journal of applied engineering sciences, 1(14),1,2011, 79-86

[35] Jumate Elena, Manea Daniela Lucia; Application of $\mathrm{X}$ Ray Diffraction (XRD) and Scanning electron microscopy(SEM) methods to the Portland cement hydration process, Journal of applied engineering sciences,2(15),1,(2012), 35-42 